\section{Response of Sophora secundiflora to Nitrogen Form and Rate}

\author{
Genhua Niu ${ }^{1}$ and Denise Rodriguez \\ Texas AgriLife Research and Extension Center at El Paso, Texas A\&M System, \\ 1380 A\&M Circle, El Paso, TX 79927 \\ Mengmeng Gu \\ Department of Plant and Soil Sciences, Mississippi State University, MS \\ 39762
}

Additional index words. Texas mountain laurel, salinity tolerance, water reuse

\begin{abstract}
Texas mountain laurel (Sophora secundiflora) is a native shrub tolerating drought, heat, windy conditions, and alkaline or wet soils. However, its availability is somewhat low and little information is available on nutrient requirement and other culture information. Two greenhouse experiments were conducted to quantify the responses of Texas mountain laurel to different forms and rates of nitrogen $(\mathrm{N})$ fertilizer. In Expt. 1, 1-year old seedlings were treated for 194 days with three $\mathrm{NO}_{3}: \mathrm{NH}_{4}$ ratios at 25:75, 50:50, and 75:25 and two rates of $N$ at 100 and $200 \mathrm{mg} \cdot \mathrm{L}^{-1}$ in a factorial design. There was no interaction between the $N$ rate and form on any growth parameters. Nitrogen form did not significantly affect shoot dry weight, root dry weight, root-to-shoot ratio, or the total dry weight. There was no significant difference between $\mathrm{N}$ rate of 100 and $200 \mathrm{mg} \cdot \mathrm{L}^{-1}$ on root dry weight, root-to-shoot ratio, or the total dry weight. The shoot dry weight of Texas mountain laurel fertilized with $100 \mathrm{mg} \cdot \mathbf{L}^{-1}$ was higher compared with that of the plants fertilized at $200 \mathrm{mg} \cdot \mathrm{L}^{-1}$. The reduced shoot dry weight at $\mathrm{N}$ of 200 $\mathrm{mg} \cdot \mathrm{L}^{-1}$ was the result of the higher substrate salinity. In Expt. 2, seedlings were fertilized with five $\mathrm{N}$ rates $\left(50,100,150,200\right.$, and $\left.250 \mathrm{mg} \cdot \mathrm{L}^{-1}\right)$ for 203 days. Plants watered with 150, 200 , and $250 \mathrm{mg} \cdot \mathrm{L}^{-1}$ were taller than those fertilized with $50 \mathrm{mg} \cdot \mathrm{L}^{-1}$. The shoot height of plants watered with $100 \mathrm{mg} \cdot \mathrm{L}^{-1}$ was only significantly different from $50 \mathrm{mg} \cdot \mathrm{L}^{-1}$. For rapid growth of Texas mountain laurel, a $N$ rate range of $\approx 150 \mathrm{mg} \cdot \mathrm{L}^{-1}$ was recommended supplied with a combination of $\mathrm{NO}_{3}-\mathrm{N}$ and $\mathrm{NH}_{4}-\mathrm{N}$ in the ratios of 0.3 to 3.0.
\end{abstract}

Texas mountain laurel (Sophora secundiflora), also called mescal bean, is a small evergreen tree native to Texas, New Mexico, and north Mexico. Its ornamental characteristics include terminal racemes of fragrant, violet-blue flowers in the spring followed by bright red seeds. Texas mountain laurel is adapted to xeric conditions (Still and Davies, 1993). Containerized Texas mountain laurel plants watered less frequently maintained similar root dry weight, shoot fresh weight, plant mortality, shoot height, the number of stems, and visual rating as those watered more frequently (Reider, 1987). It is considered an excellent landscape plant for the Southwestern states (Gilman and Watson, 1994; Ruter and Ingram, 1991); however, it has not been widely available from the nursery industry. There is little research-based information for Texas mountain laurel regarding its culture information, especially nutrient requirement.

Nitrogen is a key nutrient in manipulating plant growth and $\mathrm{N}$ is normally supplied to plants in the form of urea $\left[\mathrm{CO}\left(\mathrm{NH}_{2}\right)_{2}\right]$ and two major inorganic forms of $\mathrm{N}$ including nitrate $\left(\mathrm{NO}_{3}{ }^{-}\right)$and ammonium $\left(\mathrm{NH}_{4}{ }^{+}\right)$. Studies on many crops indicated that plants fed

Received for publication 27 June 2011. Accepted for publication 21 July 2011.

${ }^{1}$ To whom reprint requests should be addressed; e-mail gniu@ag.tamu.edu. and to determine the optimal $\mathrm{N}$ rate by irrigating them with five levels of $\mathrm{N}$ rates.

\section{Materials and Methods}

Plant materials. In Expt. 1, seeds of Texas mountain laurel were collected from the trees in the Texas AgriLife Research Center's demonstration garden. Seeds treated with concentrated sulfuric acid for 30 min were sown on 20 Nov. 2006 in plug cells $(63 \mathrm{~mL})$ filled with a germination mix of perlite, vermiculite, and peatmoss at 1:1:1 (by vol.). Seedlings were transplanted on 17 Jan. 2007 to $1.8-\mathrm{L}$ pots containing Sunshine mix No. 4 (SunGro Hort., Bellevue, WA) and composted mulch (Western Organics, Inc., Tempe, AZ) at 1:1 (by vol.) amended with $5 \mathrm{~kg} \cdot \mathrm{m}^{-3}$ dolomitic limestone (Carl Pool Earth-Safe Organics, Gladewater, TX) and $1 \mathrm{~kg} \cdot \mathrm{m}^{-3}$ Micromax (Scotts, Marysville, OH). From early May to mid-Sept. 2007, plants were grown in a shadehouse with $25 \%$ light exclusion. On 2 Oct. 2007 , plants were transplanted to $2.6-\mathrm{L}$ pots containing the same substrate as that in $1.8-\mathrm{L}$ pots and were grown in the greenhouse. In Expt. 2, seeds of Texas mountain laurel were sowed on 12 Dec. 2007. Germinated seedlings were transplanted to $15-\mathrm{cm}$ pots on $10 \mathrm{Feb}$. 2008 and then to 2.6-L pots on 21 Sept. 2008. Seedlings were grown in the greenhouse under similar conditions as in Expt. 1.

Experimental design. In Expt. 1, six treatments were created consisting of three ratios of $\mathrm{NO}_{3}: \mathrm{NH}_{4}(25: 75,50: 50,75: 25)$ and two rates of $\mathrm{N}\left(100 \mathrm{mg} \cdot \mathrm{L}^{-1}\right.$ and $\left.200 \mathrm{mg} \cdot \mathrm{L}^{-1}\right)$ in a factorial design with 10 replications. The nutrient solutions were prepared by adding fertilizers $\mathrm{KH}_{2} \mathrm{PO}_{4}, \mathrm{KNO}_{3}, \mathrm{NH}_{4} \mathrm{NO}_{3},\left(\mathrm{NH}_{4}\right)_{2} \mathrm{SO}_{4}$, and $\mathrm{K}_{2} \mathrm{SO}_{4}$ to tap water following the composition shown in Table 1. The nutrient solutions had the same level of $\mathrm{K}^{+}$and $\mathrm{PO}_{4}{ }^{3-}$ and different ratios of $\mathrm{NO}_{3}: \mathrm{NH}_{4}$ at 25:75, 50:50, and 75:25, respectively (Table 1 ). The major ions in the tap water were $\mathrm{Na}^{+}, \mathrm{Ca}^{2+}, \mathrm{Mg}^{2+}, \mathrm{Cl}^{-}$, and $\mathrm{SO}_{4}{ }^{2-}$ at $184,52.0,7.5,223.6$, and $105.6 \mathrm{mg} \cdot \mathrm{L}^{-1}$, respectively. The micronutrients were provided through incorporating Micromax into the substrate as described previously. The nutrient solutions were prepared in 100-L tanks and plants were hand-watered at $1 \mathrm{~L}$ per pot whenever the substrate surface started to dry to prevent water stress and overwatering. The leaching fraction was initially low (less than $15 \%$ ) and later increased to $\approx 25 \%$. Pots were rotated weekly within the greenhouse benches to minimize the differences in environmental conditions. Treatments were initiated on 6 Nov. 2007 and ended on 9 May 2008. The average daily air temperatures in the greenhouse for Expt. 1 were maintained at $23 \pm 3{ }^{\circ} \mathrm{C}$ (mean \pm $\mathrm{SD})$ and the daily light integral [photosynthetically active radiation $(P A R)]$ was $15 \pm$ $5 \mathrm{~mol} \cdot \mathrm{m}^{-2} \cdot \mathrm{d}^{-1}$. A $21 \times$ data logger (Campbell Scientific, Logan, UT) was used to measure temperature and light every $10 \mathrm{~s}$ and record the hourly and daily average.

In Expt. 2, nutrient solutions with five $\mathrm{N}$ rates $\left(50,100,150,200\right.$, and $\left.250 \mathrm{mg} \cdot \mathrm{L}^{-1}\right)$ were prepared by adding water-soluble fertilizer 20N-8.6P-16.7K (Peters 20-20-20; 
Table 1. Fertilizer and nutrient composition of irrigation solution of the three nitrogen forms (Expt. 1).

\begin{tabular}{lccccc}
\hline Ratios of & \multicolumn{5}{c}{ Fertilizer composition (mM) } \\
\cline { 2 - 6 } $\mathrm{NO}_{3}: \mathrm{NH}_{4}$ & $\mathrm{KH}_{2} \mathrm{PO}_{4}$ & $\mathrm{KNO}_{3}$ & $\mathrm{NH}_{4} \mathrm{NO}_{3}$ & $\left(\mathrm{NH}_{4}\right)_{2} \mathrm{SO}_{4}$ & $\mathrm{~K}_{2} \mathrm{SO}_{4}$ \\
\hline $25: 75$ & 0.25 & 0.5 & 0 & 0.75 & 0.5 \\
$50: 50$ & 0.25 & 1 & 1 & 0 & 0.25 \\
$75: 25$ & 0.25 & 1.5 & 0 & 0.25 & 0 \\
& \multicolumn{5}{c}{} \\
\hline & 1.5 & $\mathrm{NO}^{-}$ & $\mathrm{K}^{+}$ & $\mathrm{SO}_{4}{ }^{2-}$ & $\mathrm{PO}_{4}{ }^{3-}$ \\
\hline $25: 75$ & 1 & 0.5 & 1.75 & 1.25 & 0.25 \\
$50: 50$ & 0.5 & 1.5 & 1.75 & 0.25 & 0.25 \\
$75: 25$ & $\mathrm{NH}^{+}$ & 1.75 & 0.25 & 0.25 \\
\hline
\end{tabular}

Scotts, Allentown, PA) to tap water at 0.25 , $0.5,0.75,1.0$, and $1.25 \mathrm{~g} \cdot \mathrm{L}^{-1}$, respectively. The replication number was 10 . Solutions were pre-mixed in 100-L tanks and plants were hand-watered as in Expt. 1 but with high leaching fraction from the beginning to prevent salt accumulation. Treatments were initiated on 15 Oct. 2008 and ended 6 May 2009. The greenhouse air temperatures were maintained at $23.5 \pm 2.1^{\circ} \mathrm{C}($ mean $\pm \mathrm{SD})$ and the daily light integral $(P A R)$ was $13 \pm 4.9 \mathrm{~mol} \cdot \mathrm{m}^{-2} \cdot \mathrm{d}^{-1}$.

Measurement. In Expt. 1, on termination, plant height, the number of shoots, and the total length of shoots were recorded. Shoot dry weight (DW) was determined after ovendrying at $70{ }^{\circ} \mathrm{C}$ to constant weight. Leachate was collected four times for electrical conductivity (EC) and $\mathrm{pH}$ measurement during the course of the experiment. On 28 Apr. [173 d after treatment (DAT)], all containers were flushed with tap water to leach out the accumulated salts in the substrates as reflected by the increasing ECs of the leachate. At the end of the experiment, leaf greenness or relative chlorophyll concentration (measured as the optical density, SPAD reading, an acronym of Soil and Plant Analyzer Development) was recorded on two fully expanded young leaves per plant for all plants in each treatment using a portable SPAD chlorophyll meter (SPAD502; Minolta Camera Co., Osaka, Japan). Although SPAD readings do not give an absolute measure of chlorophyll concentration, they do provide a useful relative index, which is closely related to leaf chlorophyll concentration (Markwell et al., 1995; Wang et al., 2005).

Leaf net photosynthesis $\left(\mathrm{P}_{\mathrm{n}}\right)$, transpiration $(\mathrm{E})$, and stomatal conductance $\left(g_{\mathrm{S}}\right)$ were measured on four plants per treatment in the final week of the experiment by placing the recently matured leaf in the cuvette of a portable gas exchange system (CIRAS-2; PP Systems, Amesbury, MA). The environmental conditions in the cuvette were controlled at leaf temperature $=25^{\circ} \mathrm{C}$, photosynthetic photon flux $=1000 \mu \mathrm{mol} \cdot \mathrm{m}^{-2} \cdot \mathrm{s}^{-1}$, and $\mathrm{CO}_{2}$ concentration $=400 \mu \mathrm{mol} \cdot \mathrm{mol}^{-1}$. Data were recorded when the environmental conditions and gas exchange parameters in the cuvette became stable. These measurements were taken between $1000 \mathrm{HR}$ and $1200 \mathrm{HR}$.

In Expt. 2, plant height was recorded periodically during the course of the experiment. On termination, plants were destructively harvested. Shoots and roots were separated. Dry weights of shoots and roots were deter- mined by oven-drying at $70{ }^{\circ} \mathrm{C}$ to constant weight. One week before ending the experiment, leaf greenness was measured using a SPAD meter as described in Expt. 1. Leaf conductance was measured using a leaf porometer (Decagon Devices, Pullman, WA). Leachate was collected periodically for EC and $\mathrm{pH}$ measurement during the course of the experiment. On 3 Mar. (138 DAT) and 15 Apr. (181 DAT), containers with leachate EC higher than $3.0 \mathrm{dS} \cdot \mathrm{m}^{-1}$ were flushed with tap water to leach out the accumulated salts in the substrates to minimize the salinity effect because growth of Texas mountain laurel was reduced at EC of $3.0 \mathrm{dS} \cdot \mathrm{m}^{-1}$ or higher (Niu et al., 2010).

To analyze leaf $\mathrm{N}$ concentration for experiments, leaves were separated from stems and four leaf samples were randomly chosen from the 10 plants at the end of the experiment, washed three times with deionized water, and oven-dried at $70{ }^{\circ} \mathrm{C}$. Dried leaves were ground to pass a 40 -mesh screen with a stainless steel Wiley mill. Ground samples were submitted to the Soil, Water, and Air Testing Laboratory of New Mexico State University (Las Cruces, $\mathrm{NM}$ ) for total Kjeldahl $\mathrm{N}$ analysis.

Statistical analysis. A two-way analysis of variance using PROC GLM was performed for Expt. 1. When the interaction between the $\mathrm{N}$ rate and form was not significant, data were pooled to compare the main factors. For Expt. 2, linear or quadratic regression was performed and the significance was analyzed using PROC REG. To distinguish the differences among the $\mathrm{N}$ rates and forms for both experiments, Student-Newman-Keuls multiple comparison was performed. All data were analyzed using SAS software (Version 9.1.3; SAS Institute Inc., Cary, NC).

\section{Results}

Plant growth and tissue nitrogen concentration. In Expt. 1, there was no interaction between the $\mathrm{N}$ form and rate on any growth parameter and $\mathrm{N}$ form did not significantly affect growth either. Therefore, the effect of $\mathrm{N}$ rate on shoot dry weight, root dry weight, root-to-shoot ratio, and the total dry weight were pooled from $\mathrm{N}$ forms (Table 2). The shoot dry weight of Texas mountain laurel treated with $100 \mathrm{mg} \cdot \mathrm{L}^{-1}$ was higher than that treated with $200 \mathrm{mg} \cdot \mathrm{L}^{-1}$.

Nitrogen rate did not affect the $\mathrm{N}$ concentrations in leaves, stems, or roots and therefore the effect of $\mathrm{N}$ form was presented (Table 3 ). The $\mathrm{N}$ concentration of stems was $22 \%$
Table 2. Dry weights of shoots, roots and total of Texas mountain laurel as affected by nitrogen (N) rates (Expt. 1). ${ }^{\mathrm{z}}$

\begin{tabular}{lcccc}
\hline & $\begin{array}{c}\text { Shoot } \\
\left(\mathrm{mg} \cdot \mathrm{L}^{-1}\right)\end{array}$ & Root $(\mathrm{g})$ & $\begin{array}{c}\text { Root/ } \\
\text { shoot }(\mathrm{g})\end{array}$ & Total $(\mathrm{g})$ \\
\hline N rate 100 & 30.7 & 11.6 & 0.42 & 42.3 \\
N 200 & 24.4 & 10.6 & 0.45 & 35.0 \\
$t$ test & $* \mathrm{y}$ & $\mathrm{NS}$ & $\mathrm{NS}$ & $\mathrm{NS}$ \\
\hline
\end{tabular}

${ }^{\mathrm{z}}$ Data were pooled from three nitrogen forms. y*indicates significance by $t$ test at $P=0.05$. NS $=$ non-significant.

Table 3. Total nitrogen (N) concentrations of Texas mountain laurel in leaf, stem, and root as affected by $\mathrm{N}$ rate and form (Expt. 1).

\begin{tabular}{lccc}
\hline $\mathrm{N}$ form & & & \\
$\left(\mathrm{NO}_{3}: \mathrm{NH}_{4}\right)$ & Leaf $(\%)$ & Stem $(\%)$ & Root $(\%)$ \\
\hline $25: 75$ & $3.4 \mathrm{a}^{\mathrm{z}}$ & $1.5 \mathrm{~b}$ & $2.2 \mathrm{a}$ \\
$50: 50$ & $2.9 \mathrm{a}$ & $1.4 \mathrm{~b}$ & $2.2 \mathrm{a}$ \\
$75: 25$ & $2.8 \mathrm{a}$ & $1.8 \mathrm{a}$ & $2.0 \mathrm{a}$ \\
\hline
\end{tabular}

${ }^{\mathrm{z}}$ Means with same letters within the same column are not significantly different at $P=0.05$ tested by Student-Newman-Keuls multiple comparison.

higher in the $\mathrm{NO}_{3}: \mathrm{NH}_{4}$ of $75: 25$ than those in the other two forms. Although not significant, leaf $\mathrm{N}$ concentration was numerically lower in the $\mathrm{NO}_{3}: \mathrm{NH}_{4}$ of 25:75 compared with the other two forms.

In Expt. 2, on 86 DAT, Texas mountain laurels watered with 200 and $250 \mathrm{mg} \cdot \mathrm{L}^{-1} \mathrm{~N}$ were taller than those watered with 50 and $100 \mathrm{mg} \cdot \mathrm{L}^{-1} \mathrm{~N}$ (Table 4). Plants watered with 150,200 , and $250 \mathrm{mg} \cdot \mathrm{L}^{-1} \mathrm{~N}$ were taller on $133,154,184$, and 205 DAT compared with the plants watered at $50 \mathrm{mg} \cdot \mathrm{L}^{-1}$. The shoot height of plants watered with $100 \mathrm{mg} \cdot \mathrm{L}^{-1} \mathrm{~N}$ was only significantly different from $50 \mathrm{mg} \cdot \mathrm{L}^{-1}$ $\mathrm{N}$ on 205 DAT. Although not significant, plants watered with $200 \mathrm{mg} \cdot \mathrm{L}^{-1}$ had numerically longer shoot heights on 133, 154, 184, and $205 \mathrm{DAT}$ than $250 \mathrm{mg} \cdot \mathrm{L}^{-1} \mathrm{~N}$. There were both linear and quadratic relations between plant shoot height and the $\mathrm{N}$ rate of the irrigation solution $86,133,154,184$, and 205 DAT.

Plants watered with 150 and $200 \mathrm{mg} \cdot \mathrm{L}^{-1} \mathrm{~N}$ had similar final shoot and root dry weight (Table 5). Plants had lower shoot dry weight but similar root dry weight when watered with $250 \mathrm{mg} \cdot \mathrm{L}^{-1} \mathrm{~N}$ compared with 200 $\mathrm{mg} \cdot \mathrm{L}^{-1} \mathrm{~N}$. The root-to-shoot ratio $(\mathrm{R} / \mathrm{S})$ was higher in plants watered with $50 \mathrm{mg} \cdot \mathrm{L}^{-1} \mathrm{~N}$ compared with other $\mathrm{N}$ rates. However, leaf $\mathrm{N}$ concentration was lower in plants watered with $50 \mathrm{mg} \cdot \mathrm{L}^{-1} \mathrm{~N}$ compared with other $\mathrm{N}$ rates. Shoot DW, root DW, R/S, and leaf N concentration had significant linear and quadratic relationships as $\mathrm{N}$ rate increased. Shoot DW started to decrease as $\mathrm{N}$ rate increased from 200 to $250 \mathrm{mg} \cdot \mathrm{L}^{-1}$. Although not statistically significantly, leaf $\mathrm{N}$ concentration tended to decrease as $\mathrm{N}$ rate increased from $100 \mathrm{mg} \cdot \mathrm{L}^{-1}$.

Leachate electrical conductivity and $\mathrm{pH}$. In Expt. 1, plants watered with $200 \mathrm{mg} \cdot \mathrm{L}^{-1} \mathrm{~N}$ had higher leachate EC than those watered with $100 \mathrm{mg} \cdot \mathrm{L}^{-1} \mathrm{~N}$ regardless of $\mathrm{NO}_{3}: \mathrm{NH}_{4}$ ratio from 105 to 184 DAT (Fig. 1A). The leachate EC was $4.2,3.3$, and $3.3 \mathrm{dS} \cdot \mathrm{m}^{-1}$ for 
$100 \mathrm{mg} \cdot \mathrm{L}^{-1} \mathrm{~N}$ with $\mathrm{NO}_{3}: \mathrm{NH}_{4}$ ratios of $25: 75$, 50:50, and 75:25, respectively, on 105 DAT. Plants in the $200 \mathrm{mg} \cdot \mathrm{L}^{-1} \mathrm{~N}$ treatments had EC at least $2.0 \mathrm{dS} \cdot \mathrm{m}^{-1}$ higher than their $100 \mathrm{mg} \cdot \mathrm{L}^{-1}$ $\mathrm{N}$ counterparts, respectively. All plants had higher EC on $132 \mathrm{DAT}$, and EC in $200 \mathrm{mg} \cdot \mathrm{L}^{-1}$ $\mathrm{N}$ at $50: 50 \mathrm{NO}_{3}: \mathrm{NH}_{4}$ ratio was $8.4 \mathrm{dS} \cdot \mathrm{m}^{-1}$. After all the containers were flushed with tap water on 174 DAT, all the ECs decreased below their respective level on 105 DAT except $100 \mathrm{mg} \cdot \mathrm{L}^{-1} \mathrm{~N}$ at $50: 50 \mathrm{NO}_{3}: \mathrm{NH}_{4}$ ratio. EC values of different treatments on 184 DAT were close to their values on 174 DAT, respectively.

Plants treated with $100 \mathrm{mg} \cdot \mathrm{L}^{-1} \mathrm{~N}$ with $\mathrm{NO}_{3}: \mathrm{NH}_{4}$ ratios of $75: 25$ had the highest leachate $\mathrm{pH}$ on $105,132,174$, and 184 DAT and plants treated with $200 \mathrm{mg} \cdot \mathrm{L}^{-1} \mathrm{~N}$ with $\mathrm{NO}_{3}: \mathrm{NH}_{4}$ ratios of 50:50 and 25:75 had the lowest $\mathrm{pH}$ on 132, 174, and 184 DAT (Fig. 1B). The $\mathrm{pH}$ of the leachate was between 6.5 and 7.5 for all treatments on 105 DAT and 132 DAT. After all the containers were flushed with tap water on $174 \mathrm{DAT}$, leachate $\mathrm{pH}$ of $100 \mathrm{mg} \cdot \mathrm{L}^{-1}$ $\mathrm{N}$ at $75: 25 \mathrm{NO}_{3}: \mathrm{NH}_{4}$ ratio increased to 7.7 , whereas $200 \mathrm{mg} \cdot \mathrm{L}^{-1} \mathrm{~N}$ at $25: 75 \mathrm{NO}_{3}: \mathrm{NH}_{4}$ and 50:50 $\mathrm{NO}_{3}: \mathrm{NH}_{4}$ decreased to 5.9 and 6.4, respectively.

In Expt. 2, leachate EC of all treatments was between $1.4 \mathrm{dS} \cdot \mathrm{m}^{-1}$ and $3.1 \mathrm{dS} \cdot \mathrm{m}^{-1}$ from 15 Oct. 2008 (0 DAT) to 9 Feb. 2009 (117 DAT) (Fig. 2). The leachate ECs of all treatments except for $50 \mathrm{mg} \cdot \mathrm{L}^{-1} \mathrm{~N}$ increased and were in the range between $2.8 \mathrm{dS} \cdot \mathrm{m}^{-1}$ and $5.8 \mathrm{dS} \cdot \mathrm{m}^{-1}$ on $138 \mathrm{DAT}$, and containers were flushed with tap water on 138 DAT and 151 DAT to lower the EC of all treatments. $\mathrm{pH}$ of all treatments was between 6.4 and 7.7 from 0 DAT to 117 DAT (Fig. 2). The $\mathrm{pH}$ of all treatments except for $50 \mathrm{mg} \cdot \mathrm{L}^{-1} \mathrm{~N} 50 \mathrm{de}$ creased to below 6.5 on 138 DAT. The $\mathrm{pH}$ of all treatments decreased again to a range between 6.0 and 6.7 on 198 DAT.

Gas exchanges and SPAD. There was no interaction between the $\mathrm{N}$ rate and form in SPAD readings. The $\mathrm{N}$ form only had a significant effect on SPAD reading, so the $t$ test was used to separate the difference between the two $\mathrm{N}$ rates in all the other measurements. Transpiration, $g_{\mathrm{S}}$, and $\mathrm{P}_{\mathrm{n}}$ of Texas mountain laurel treated with $100 \mathrm{mg} \cdot \mathrm{L}^{-1} \mathrm{~N}$ were significantly higher than the ones treated with the $200 \mathrm{mg} \cdot \mathrm{L}^{-1} \mathrm{~N}$ rate (Table 6).

Both $\mathrm{N}$ rate and $\mathrm{N}$ form had a significant effect on SPAD reading. The SPAD reading of Texas mountain laurel treated with 100 $\mathrm{mg} \cdot \mathrm{L}^{-1} \mathrm{~N}$ was 66.3 , which was significantly higher than those treated with $200 \mathrm{mg} \cdot \mathrm{L}^{-1} \mathrm{~N}$ (56.2) (Table 7). There was no significant difference on SPAD reading between Texas mountain laurel treated with 25:75 $\left(\mathrm{NO}_{3}: \mathrm{NH}_{4}\right)$ and 50:50 $\left(\mathrm{NO}_{3}: \mathrm{NH}_{4}\right)$. The SPAD reading was significantly lower in Texas mountain laurel treated with 75:25 $\left(\mathrm{NO}_{3}: \mathrm{NH}_{4}\right)$.

\section{Discussion}

The effect of $\mathrm{NO}_{3}: \mathrm{NH}_{4}$ ratio and the $\mathrm{N}$ form on plant growth and physiological response depends on species. Growth (shoot dry weight, root dry weight, $\mathrm{R} / \mathrm{S}$, and the total
Table 4. Plant shoot height of Texas mountain laurel as affected by nitrogen (N) rates (Expt. 2) on 5, 86, $133,154,184$, and $205 \mathrm{~d}$ after treatment initiation (DAT), respectively.

\begin{tabular}{lcccccc}
\hline & \multicolumn{7}{c}{ Plant shoot ht $(\mathrm{cm})$} \\
\cline { 2 - 7 } N rate $\left(\mathrm{mg} \cdot \mathrm{L}^{-1}\right)$ & 5 DAT & $86 \mathrm{DAT}$ & $133 \mathrm{DAT}$ & $154 \mathrm{DAT}$ & $184 \mathrm{DAT}$ & $205 \mathrm{DAT}$ \\
\hline 50 & 7.8 & $7.7 \mathrm{~b}^{\mathrm{z}}$ & $9.2 \mathrm{~b}$ & $9.9 \mathrm{~b}$ & $11.0 \mathrm{c}$ & $12.8 \mathrm{c}$ \\
100 & 7.7 & $7.7 \mathrm{~b}$ & $9.9 \mathrm{~b}$ & $13.0 \mathrm{ab}$ & $16.0 \mathrm{bc}$ & $18.3 \mathrm{~b}$ \\
150 & 7.5 & $9.2 \mathrm{ab}$ & $13.3 \mathrm{a}$ & $16.2 \mathrm{a}$ & $22.6 \mathrm{a}$ & $23.1 \mathrm{ab}$ \\
200 & 7.6 & $11.3 \mathrm{a}$ & $16.6 \mathrm{a}$ & $17.1 \mathrm{a}$ & $26.1 \mathrm{a}$ & $28.5 \mathrm{a}$ \\
250 & 7.5 & $11.3 \mathrm{a}$ & $15.5 \mathrm{a}$ & $16.8 \mathrm{a}$ & $21.3 \mathrm{ab}$ & $23.0 \mathrm{ab}$
\end{tabular}

Significance of regression

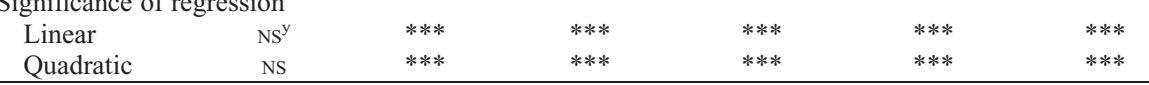

${ }^{z}$ Means with same letters within the same column are not significantly different at $P=0.05$ tested by Student-Newman-Keuls multiple comparison.

${ }^{\mathrm{y}} \mathrm{NS}$ indicates non-significant at $P=0.05$ and ${ }^{* * *}$ indicates significance at $P=0.001$.

Table 5. Shoot and root dry weight (DW), root-to-shoot ratio (R/S), and the total nitrogen concentration (leaf $\mathrm{N}$ ) in leaves of Texas mountain laurel watered with different nitrogen rate (Expt. 2).

\begin{tabular}{lcccc}
\hline Nitrogen rate $\left(\mathrm{mg} \cdot \mathrm{L}^{-1}\right)$ & Shoot DW $(\mathrm{g})$ & Root DW $(\mathrm{g})$ & $\mathrm{R} / \mathrm{S}(\%)$ & Leaf N \\
\hline 50 & $3.99 \mathrm{~d}^{2}$ & $3.26 \mathrm{~b}$ & $0.85 \mathrm{a}$ & $2.11 \mathrm{~b}$ \\
100 & $7.14 \mathrm{dc}$ & $3.27 \mathrm{~b}$ & $0.47 \mathrm{~b}$ & $3.24 \mathrm{a}$ \\
150 & $11.81 \mathrm{ab}$ & $4.33 \mathrm{ab}$ & $0.39 \mathrm{~b}$ & $3.02 \mathrm{a}$ \\
200 & $14.90 \mathrm{a}$ & $5.28 \mathrm{a}$ & $0.38 \mathrm{~b}$ & $2.94 \mathrm{a}$ \\
250 & $10.38 \mathrm{bc}$ & $5.13 \mathrm{a}$ & $0.56 \mathrm{~b}$ & $2.76 \mathrm{a}$ \\
& & & & \\
Significance & $* * * \mathrm{y}$ & $* * *$ & $* * *$ & $* * *$ \\
$\quad$ Linear & $* * *$ & $* * *$ & $* * *$ & $* * *$ \\
$\quad$ Quadratic & & & & \\
\hline
\end{tabular}

${ }^{\mathrm{z}}$ Means with same letters within the same column are not significantly different at $P=0.05$ tested by Student-Newman-Keuls multiple comparison.

y*** Significant at $P=0.001$.
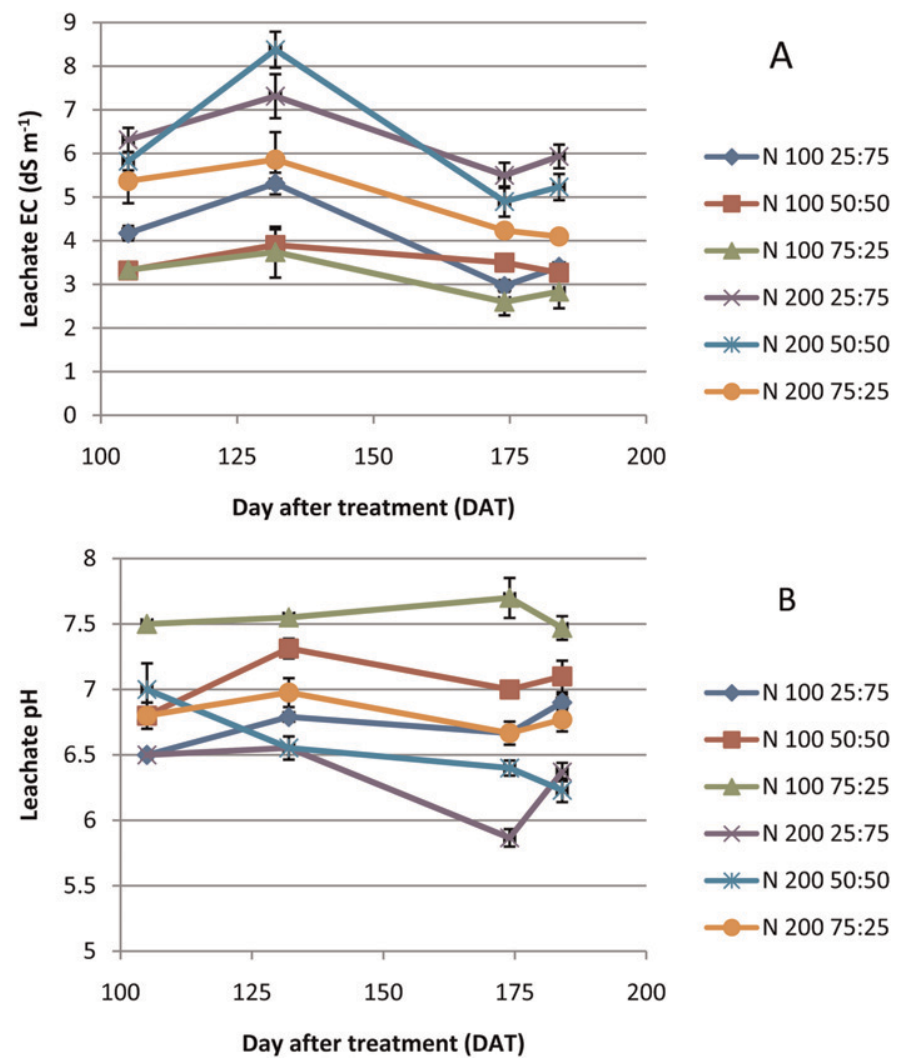

Fig. 1. Leachate electrical conductivity (EC) and pH of Texas mountain laurel measured on 105, 132, 174, and $184 \mathrm{~d}$ after treatment (DAT) as affected by nitrogen rate and form (Expt. 1). Vertical bars represent SES $(n=4)$. 

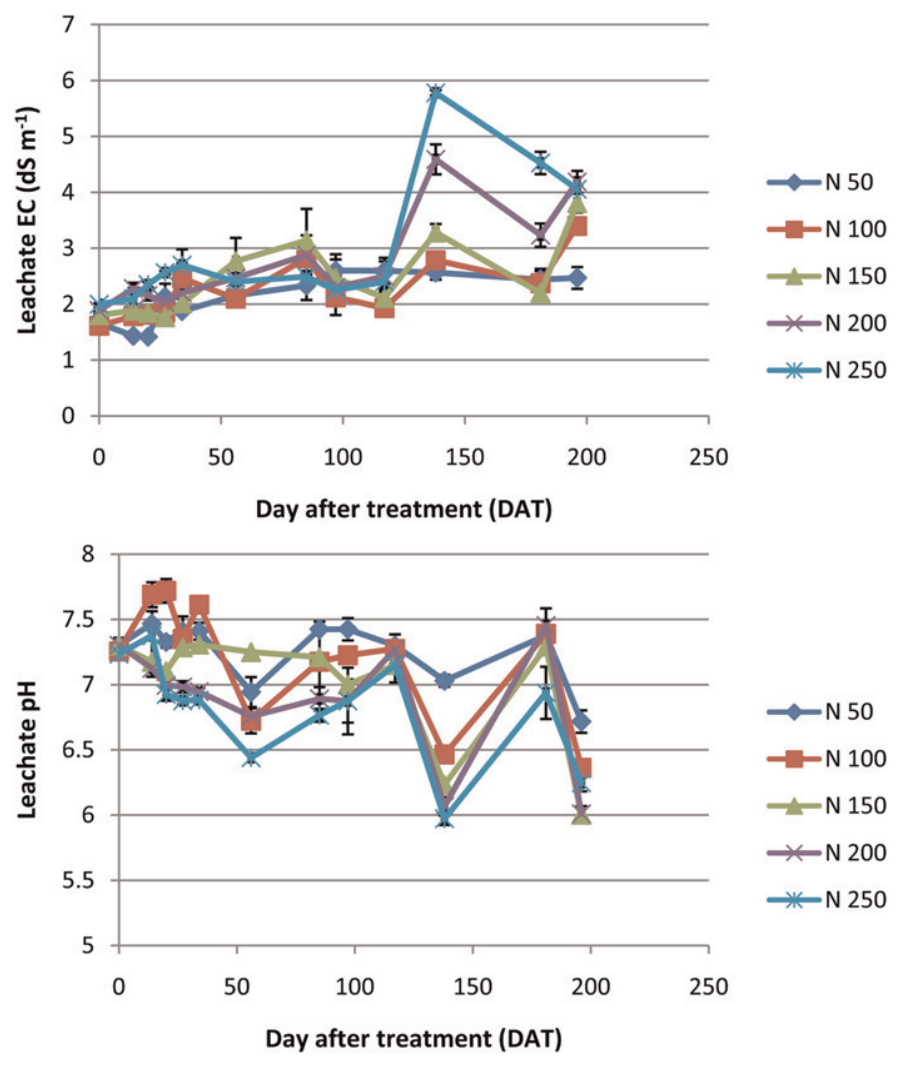

Fig. 2. Time course of leachate electrical conductivity (EC) and $\mathrm{pH}$ of Texas mountain laurel plants irrigated at five nitrogen rates (Expt. 2). Containers were flushed with tap water on 3 Mar. [138 d after treatment (DAT)] and $15 \mathrm{Apr}$. (181 DAT) when leachate EC were higher than $3.0 \mathrm{dS} \cdot \mathrm{m}^{-1}$. Vertical bars represent SES $(n=4)$.

Table 6. Transpiration (E), stomatal conductance $\left(g_{\mathrm{S}}\right)$, and net photosynthesis $\left(\mathrm{P}_{\mathrm{n}}\right)$ of Texas mountain laurel treated with $100 \mathrm{mg} \cdot \mathrm{L}^{-1}(\mathrm{~N}$ $100)$ and $200 \mathrm{mg} \cdot \mathrm{L}^{-1}(\mathrm{~N} 200)$ nitrogen rates (Expt. 1).

\begin{tabular}{lccc}
\hline N rate & $\mathrm{E}$ & $g_{\mathrm{S}}$ & $\mathrm{P}_{\mathrm{n}}$ \\
\hline $\mathrm{N} 100$ & 1.77 & 101.75 & 8.14 \\
$\mathrm{~N} 200$ & 1.46 & 76.17 & 6.88 \\
$t$ test & $* \mathrm{z}$ & $*$ & $*$ \\
\hline
\end{tabular}

z* Significance by $t$ test at $P=0.05$.

Table 7. SPAD readings of Texas mountain laurel as affected by nitrogen $(\mathrm{N})$ rate and form (Expt. 1).

\begin{tabular}{lc}
\hline N rate & SPAD \\
\hline Nitrogen rate & $66.3 \mathrm{a}^{\mathrm{z}}$ \\
$\mathrm{N} 100$ & $56.2 \mathrm{~b}$ \\
$\mathrm{~N} 200$ & \\
& \\
Nitrogen form $\left(\mathrm{NO}_{3}: \mathrm{NH}_{4}\right)$ & $64.9 \mathrm{a}$ \\
25:75 & $65.0 \mathrm{a}$ \\
50:50 & $54.7 \mathrm{~b}$ \\
$75: 25$ & \\
\hline
\end{tabular}

${ }^{2}$ Means followed by the same letter within each section are not significantly different at $P=0.05$ tested by Student-Newman-Keuls multiple comparison.

dry weight) and gas exchange $\left(\mathrm{E}, g_{\mathrm{S}}\right.$, and $\left.\mathrm{P}_{\mathrm{n}}\right)$ of Texas mountain laurel were unaffected by the $\mathrm{NO}_{3}: \mathrm{NH}_{4}$ ratios investigated in the study (25:75, 50:50, and 75:25) when $\mathrm{N}$ was applied at $100 \mathrm{mg} \cdot \mathrm{L}^{-1}$ or $200 \mathrm{mg} \cdot \mathrm{L}^{-1}$. The total dry weight of hydroponically grown purslane (Palaniswamy et al., 1997) and growth, flower yield, and quality of greenhouse-grown 'Royalty' rose (Cabrera et al., 1996) and 'Bridal Pink' rose (Cabrera, 2001) were also unaffected by the ratio of $\mathrm{NO}_{3}: \mathrm{NH}_{4}$.

The effect of $\mathrm{N}$ form on total $\mathrm{N}$ concentrations in plant tissue is also species-dependent. Shoot N concentrations of three ornamental woody shrubs, Cotoneaster dammeri 'Royal Beauty', Pyrancantha coccinea 'Wyatti', and Weigela florida, were higher when $\mathrm{NH}_{4}-\mathrm{N}$ was applied compared with $\mathrm{NO}_{3}-\mathrm{N}$ (Guillam et al., 1980). Research on dieffenbachia (Becker et al., 2008), rose (Cabrera et al., 1996), and pepper (Bar-Tal et al., 2001a) found that $\mathrm{N}$ uptake was improved and $\mathrm{N}$ concentration was higher in plants supplied with $\mathrm{NH}_{4}-\mathrm{N}$. In Texas mountain laurel, although not significant, leaf $\mathrm{N}$ concentrations tended to be higher in the $\mathrm{NO}_{3}: \mathrm{NH}_{4}$ of $25: 75$, whereas stem $\mathrm{N}$ concentration was higher in the $\mathrm{NO}_{3}: \mathrm{NH}_{4}$ of 75:25. However, the stem $\mathrm{N}$ concentrations were $\approx 50 \%$ those in the leaves. The different $\mathrm{NO}_{3}: \mathrm{NH}_{4}$ also had an effect on SPAD readings with higher SPAD readings correlated with a higher percentage of $\mathrm{NH}_{4}-\mathrm{N}$ in the solution.

Irrigating container plants at optimal fertilizer rate is important. Applying a less than optimal amount usually reduces plant growth and affects plant quality, whereas applying higher than the optimal rate is not only a waste of resources, but also leads to the possibility of increased fertilizer runoff and pollution of environment of soil and water.
Wu et al. (2008) reported that the growth of Sophora davidii seedlings, a perennial shrub native to China and widely distributed in dry valleys, performed better with a low $\mathrm{N}$ rate (92 $\mathrm{mg} \cdot \mathrm{kg}^{-1}$ ) soil compared with no N supply or a high rate of $184 \mathrm{mg} \cdot \mathrm{kg}^{-1}$ irrigated with three water supply regimes $(80 \%, 40 \%$, and $20 \%$ field water capacity). Similar to $S$. davidii, Texas mountain laurel is also adapted to dry regions. Cabrera (2003) reported that maximum dry weight yields for Ilex opaca 'Hedgeholly' and Lagerstroemia $\times$ 'Tonto' plants were observed at leaf $\mathrm{N}$ concentrations of $2.53 \%$ and $2.65 \%$, respectively, and their shoot dry biomass and leaf area increased significantly with applied $\mathrm{N}$ concentrations up to $60 \mathrm{mg} \cdot \mathrm{L}^{-1}$, but higher levels caused significant reductions in these parameters. The optimal $\mathrm{N}$ rate may be related to growth habit or rapid or slow growth. For Boronia (Boronia megastigma), an Australian woody shrub, increasing N levels from 0 to $350 \mathrm{mg} \cdot \mathrm{L}^{-1}$ in the nutrient solution increased production of nodes, later shoots from these nodes, and further nodes on these lateral shoots (Reddy and Menary, 1989).

Higher $\mathrm{N}$ rate application may cause salt accumulation in the root zone. Plants supplied with $200 \mathrm{mg} \cdot \mathrm{L}^{-1} \mathrm{~N}$ had leachate EC in the $4.2 \mathrm{dS} \cdot \mathrm{m}^{-1}$ to $8.4 \mathrm{dS} \cdot \mathrm{m}^{-1}$ range, which on average was $2.3 \mathrm{dS} \cdot \mathrm{m}^{-1}$ higher than plants supplied with $100 \mathrm{mg} \cdot \mathrm{L}^{-1} \mathrm{~N}$. The leachate EC levels of both $100 \mathrm{mg} \cdot \mathrm{L}^{-1} \mathrm{~N}$ and $200 \mathrm{mg} \cdot \mathrm{L}^{-1}$ $\mathrm{N}$ treatments were substantially higher than the rates recommended for best management practices for container-grown plants (Yeager, 2000). Niu et al. (2010) reported that the growth and gas exchange rates of Texas mountain laurel were reduced when salinity of irrigation water was $3.0 \mathrm{dS} \cdot \mathrm{m}^{-1}$ (with leachate salinity of 4 to $9 \mathrm{dS} \cdot \mathrm{m}^{-1}$ ) or higher compared with salinity of irrigation water at $1.6 \mathrm{dS} \cdot \mathrm{m}^{-1}$ (control), although no visual foliar salt damage was observed. The lower gas exchange rates, shoot dry weight, and SPAD reading observed in plants watered with $200 \mathrm{mg} \cdot \mathrm{L}^{-1}$ $\mathrm{N}$ was obviously the result of higher root zone EC compared $100 \mathrm{mg} \cdot \mathrm{L}^{-1} \mathrm{~N}$. The salinity in the root zone in Expt. 2 was closely monitored and controlled and there was significant growth enhancement when $\mathrm{N}$ rate was increased from 100 to $200 \mathrm{mg} \cdot \mathrm{L}^{-1}$. The optimal $\mathrm{N}$ rate for Texas mountain laurel should be determined primarily based on the results in Expt. 2.

In summary, both $\mathrm{N}$ form $\left(\mathrm{NO}_{3}: \mathrm{NH}_{4}\right.$ of $25: 75,50: 50,75: 25)$ and rate (100 and 200 $\mathrm{mg} \cdot \mathrm{L}^{-1}$ ) did not interactively affect Texas mountain laurel in any growth parameter, gas exchange and leachate salinity, and $\mathrm{pH}$. Shoot growth was reduced by the higher $\mathrm{N}$ rate $\left(200 \mathrm{mg} \cdot \mathrm{L}^{-1}\right)$ compared with $100 \mathrm{mg} \cdot \mathrm{L}^{-1}$, which was the result of the higher substrate salinity as reflected in high leachate salinity. Nitrogen form did not affect any growth parameter. Lower $\mathrm{N}$ rate $\left(0\right.$ to $\left.100 \mathrm{mg} \cdot \mathrm{L}^{-1}\right)$ resulted in slower growth compared with higher rates. The optimal $\mathrm{N}$ rate range is $\approx 150 \mathrm{mg} \cdot \mathrm{L}^{-1}$ for rapid growth of Texas mountain laurel, which can be supplied by a combination of $\mathrm{NO}_{3}-\mathrm{N}$ and $\mathrm{NH}_{4}-\mathrm{N}$. 


\section{Literature Cited}

Bar-Tal, A., B. Aloni, L. Karni, J. Oserovitz, A. Hazan, M. Itach, S. Gantz, A. Avidan, I. Polsalski, N. Tratkovski, and R. Rosenberg. 2001a. Nitrogen nutrition of greenhouse pepper. I. Effects of nitrogen concentration and $\mathrm{NO}_{3}: \mathrm{NH}_{4}$ ratio on yield, fruit shape, and incidence of blossom-end rot in relation to plant mineral composition. HortScience 36:1244-1251.

Bar-Tal, A., B. Aloni, L. Karni, and R. Rosenberg. 2001b. Nitrogen nutrition of greenhouse pepper. II. Effects of nitrogen concentration and $\mathrm{NO}_{3}: \mathrm{NH}_{4}$ ratio on growth, transpiration, and nutrient uptake. HortScience 36:1252-1259.

Becker, S.J., M.T. Lao, and M.L. Segura. 2008. Effect of empirical models of nitrogen uptake under different nitrogen sources in Dieffebachia amoena. HortScience 43:575-579.

Bernardo, L.M., R.B. Clark, and J.W. Maranville. 1984. Nitrate/ammonium ratio effects on nutrient solution $\mathrm{pH}$, dry matter yield, and nitrogen uptake of sorghum. J. Plant Nutr. 7:1389-1400.

Cabrera, R.I. 2001. Effect of $\mathrm{NaCl}$ salinity and nitrogen fertilizer formulation on yield and nutrient status of roses. Acta Hort. 547:255-260.

Cabrera, R.I. 2003. Nitrogen balance for two container-grown woody ornamental plants. Sci. Hort. 97:297-308.

Cabrera, R.I., R.Y. Evans, and J.L. Paul. 1996. The uptake of nitrate and ammonium by greenhouse roses. Acta Hort. 424:53-58.

Cao, W. and T.W. Tibbitts. 1992. $\mathrm{NO}_{3} / \mathrm{NH}_{4}$ mixtures enhance growth in potatoes. HortScience 27:665 (abstr.).
Gamiely, S., W.M. Randle, H.A. Mills, D.A. Smittle, and G.I. Banna. 1991. Onion plant growth, bulb quality, and water uptake following ammonium and nitrate nutrition. HortScience 26:1061-1063.

Guillam, C.H., T.A. Fretz, and W.J. Sheppard. 1980. Effect of nitrogen form and rate on elemental content and growth of pyracantha, cotonester and weigela. Sci. Hort. 13:173179

Gilman, E.F. and D.G. Watson. 1994. Sophora secundiflora (Texas mountain laurel). Florida Cooperative Extension Service, Fact Sheet ST597, University of Florida.

Hahne, K.S. and U.K. Schuch. 2006. Nitrogen form and concentration affect nitrogen leaching and seedling growth of Prosopis velutina. HortScience 41:239-243.

Kafkafi, U. 1990. Root temperature, concentration and the ratio $\mathrm{NO}_{3} / \mathrm{NH}_{4}$ effect on plant development. J. Plant Nutr. 13:1291-1306.

Markwell, J., J.C. Osterman, and J.L. Mitchell 1995. Calibration of the SPAD-502 leaf chlorophyll meter. Photosynth. Res. 46:467-472.

Niu, G., M. Gu, and D.S. Rodriguez. 2010. Salinity tolerance of Sophora secundiflora and Cercis canadensis var. Mexicana. HortScience 45: 424-427.

Palaniswamy, U.R., R. McAvoy, and B. Bible. 1997. Omega-3-fatty acid concentration in Portulaca oleraceae L. is altered by the source of nitrogen in hydroponic solution. HortScience 32:463 (abstr.).

Reddy, K.S. and R.C. Menary. 1989. Vegetative growth, flowering and leaf nutrient concentra- tion of boronia as affected by nitrogen level and form. Sci. Hort. 40:335-344.

Reider, L.M. 1987. Evaluation of two watering regimes on three species of containerized native Texas woody ornamental plants. Thesis, Texas Tech University.

Romero, F.R., R.J. Gladon, and H.G. Taber. 2004. Nitrogen source and concentration affect growth and performance of bedding-plant impatiens. HortScience 39:776 (abstr.).

Ruter, J.M. and D.L. Ingram. 1991. Germination and morphology of Sophora secundiflora seeds following scarification. HortScience 26:256257.

Santamaria, P. and A. Elia. 1997. Producing nitratefree endive heads: Effect of nitrogen form on growth, yield, and ion composition of endive. J. Amer. Soc. Hort. Sci. 122:140-145.

Still, D.W. and F.T. Davies. 1993. Water use, water-use efficiency and growth analysis of selected woody ornamental species under a nonlimiting water regime. Sci. Hort. 53:213-223.

Wang, Q., J. Chen, R.H. Stamps, and Y. Li. 2005. Correlation of visual quality grading and SPAD reading of green-leaved foliage plants. J. Plant Nutr. 28:1215-1225.

Wu, F., W. Bao, F. Li, and N. Wu. 2008. Effects of drought stress and $\mathrm{N}$ supply on the growth, biomass partitioning and water use efficiency of Sophora davidii seedlings. Environ. Exp. Bot. 63:248-255.

Yeager, T.H. 2000. Status of best management practices for container nurseries. Proc. Fla. State Hort. Soc. 113:148-149. 